\section{ECONOMICS}

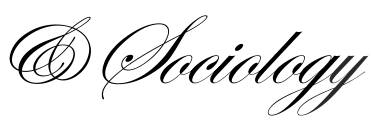

Fényes, H., Mohácsi, M., \& Pallay, K. (2021). Career consciousness and commitment to graduation among higher education students in Central and Eastern Europe. Economics and Sociology, 14(1), 61-75. doi:10.14254/2071789X.2021/14-1/4

\title{
CAREER CONSCIOUSNESS AND COMMITMENT TO GRADUATION AMONG HIGHER EDUCATION STUDENTS IN CENTRAL AND EASTERN EUROPE
}

\author{
Hajnalka Fényes \\ University of Debrecen, \\ Debrecen, Hungary \\ E-mail: \\ fenyes.zsussanna@arts.unideb.bu \\ ORCID 0000-0002-1509-0534
}

Márta Mohácsi

University of Debrecen,

Debrecen, Hungary

E-mail:

mobacsi.marta@arts.unideb.bu

ORCID 0000-0002-3031-2342

\section{Katalin Pallay \\ University of Debrecen, \\ Debrecen, Hungary; \\ Ferenc Rákéczi II Transcarpathian \\ Hungarian College of Higher \\ Education, Berehove, Ukraine \\ E-mail:pallayk316@,kmf.uz.ua \\ ORCID 0000-0003-3833-8368}

Received: April, 2020

1st Revision: December, 2020

Accepted: March, 2021

DOI: $10.14254 / 2071-$

789X.2021/14-1/4

JEL Classification: J24

\begin{abstract}
In this paper, we examine higher education students' motivations to continue their studies in higher education and their commitment to graduation based on a survey $(\mathrm{N}=2,199)$, conducted in 2018 and 2019 in five countries of the Central and Eastern Europe. According to our hypothesis, career-conscious students take into account primarily the predictions of the human capital theory with respect to further studies (e.g., well-paying job, holding a prestigious profession). Additionally, they are also more committed to graduating (they are more persistent) than other students. Based on the principal component analysis of motivations for further study and persistence indicators, we find that career consciousness and persistence are positively correlated. Through regression analysis, we also show that males are less career-conscious and less persistent than females. In addition, the results imply that even socially advantaged students might not all be career-conscious and persistent. Students whose tuition is paid for by the state can also be poorly motivated and may lack career consciousness. As regards the field of study, students in Humanities are not likely to be career-conscious, while the risk of attrition is present among those who study Economics, Business, or Sciences. This highlights the need for an educational policy intervention.
\end{abstract}

Keywords human capital theory, motivations to study, higher education, student persistence, Central and Eastern Europe, quantitative analysis. 


\section{Introduction}

Students' motivation to continue their studies in higher education and their commitment to graduation (in higher education research the latter concept is often referred to as persistence, which is the inverse of attrition risk) are important fields of education research, but they are also discussed in psychology and sociology. Concerning the economic aspects, the motivation to study further in higher education is often considered in the framework of human capital theory, since the decision to enter higher education is influenced by the wage premium of a higher education degree as compared to a secondary degree, as well as by the social prestige of subsequent employment.

The goal of our research is to explore the persistence of students in higher education and the motives to continue their studies in higher education. According to our hypothesis, careerconscious students decide to enter higher education based on the goals of subsequent income and career prospects, and are also persistent, that is, committed to completing their studies, to which they devote considerable effort. Revealing a connection between persistence and careerconsciousness is the main novelty of our study. Furthermore, we also examine the sociodemographic background variables and programme characteristics which affect these two factors.

In the theoretical section, we specify the definition of career and career consciousness, and briefly present the essence of human capital theory and the types of motivations behind further studies, based on literature. Subsequently, we discuss persistence and its influencing factors; then, following the literature, we formulate our hypotheses. In the empirical section, we use the Central and Eastern European database (2018-2019, N=2,199) to conduct the principal component analysis, with 11 items of motives behind further studies and four indicators of persistence. We also analyse the relationship of the resulting principal components with the students' gender, social background, country and field of studies, and the form of funding.

\section{Literature review}

\section{Career consciousness and motives behind further studies}

The extent to which individuals (students, in this case) are career-conscious is a decisive factor in career management. The term "career" may describe a profession or a life lived working. Synonyms of career include path, course of life, achievement, progress, and success. The term is frequently used to denote progress within a firm, instead of social mobility between workplaces (Arthur et al., 2005).

A protean career describes an individualistic and self-driven career, which is based on individual values and the subjective interpretation of success (Hall, 1996). According to the Kaleidoscope model (Sullivan et al., 2009), three factors are important in the workplace: first, autonomy and responsibility as well as improvement and learning opportunities; second, the possibility of work-life balance; third, harmony between individual and organisational values. In the course of a career, the weight of each factor is not constant.

Most young people who are about to graduate from secondary education do not have a clear career plan. Career decisions are influenced by the parents, social background, as well as by future earnings, status, and working conditions. Furthermore, they are also affected by their peer group, the media, and the motivating power of their instructors. It can also be shown that the peer group has a larger impact on females' career plans than on males' intentions (Nimra et al., 2019; Kazi-Akhlaq, 2017). 
Being conscious in relation to the career or choice of profession means that young people become aware of career opportunities and the respective requirements (Tuckman, 1974). A conscious choice of profession requires that students collect information on employment possibilities and make their decision based on the employment prospects and earnings after graduation. It is important to highlight that students with a determined career plan are more motivated and more committed to studying (CEDEFOP, 2017).

Houle (1961) explored the motives behind entering higher education at the initial stage of the expansion process. According to his theory, motives can be classified into academic orientation, goal orientation, and activity orientation. Academically oriented students are enthusiastic about learning more and are committed to their intellectual development. Goaloriented students apply to higher education institutions to build a career. Activity-oriented students, in contrast, opt for higher education to meet new people and delay their entry into the labour market. Clark and Trow's (1966) results are similar, but they distinguish academic, professional, and collegial motives. The academic motive refers to the desire to learn, the professional one is related to career building, while the collegial motivation concerns the social network within the university. In most cases, motives behind further studies are divided into extrinsic and intrinsic ones (Lepper, 1988). Applicants' intrinsic motives consist of the interest towards the field of study and personal development, while extrinsic motives comprise economic considerations (Knutsen, 2011). Pires (2009) also emphasises intrinsic and extrinsic motivations, while identifying so-called derivative motives in the decision to pursue further studies. Intrinsic motives contain the faith in studying, the love for learning, the reinforcement of social relationships, as well as professional considerations, which comprise career-building and skill improvement. Extrinsic motives include economic factors (monetary advantages, ease of employment) and external pressure from the family, parents, friends, or the workplace. The derivative motive comprises the avoidance of boredom and the postponement of having to work. Students who are forced into higher education by their parents are not interested in deepening their knowledge and simply aim to graduate (Kot, 2017).

Thompson and Subich (2006) reveal that students of higher social status are more decisive and goal-oriented, and make career decisions easier. In addition to the applicant's social background, the decision to enter higher education is also largely influenced by gender and ethnicity (Conno -Britain, 2004). As regards gender, it is possible to outline professional stereotypes. While males are more attracted to STEM programmes (Science, Technology, Engineering and Mathematics), females prefer interpersonal, communication-intensive, and helping professions (e.g., education, nursing, patient care, etc.) (Balica et al., 2004).

According to human capital theory (Mincer, 1958; Becker, 1964; Schultz, 1971), individual investment into education increases future productivity. In addition, the return to the investment into higher education is materialised in subsequent higher earnings and ease of finding employment. In this study, we devote special attention to the extent to which students take into account in their decision to pursue further studies the predictions of human capital theory (well-paying jobs, ease of finding employment, and prestigious profession obtainable through a higher education degree). ${ }^{1}$

The wage premium of higher education in Hungary has been presented in numerous publications, even after the expansion of higher education in the 2000s (Galasi, 2005; 2007, Kertesi-Köllö, 2007, Csillag et al., 2018). The latter is due to the rising demand for graduates, which accompanied the increase in supply, resulting in an only slightly reduced wage premium for higher education degrees. In post-socialist countries, the share of graduates is still below

\footnotetext{
${ }^{1}$ Teichler and Kehm (1995) argue that the decision about the specific field and programme of study is also influenced by the subsequent return (future earnings and social status), but unfortunately, we do not have data in relation to the motives behind the decision to choose specific institutions or programmes.
} 
Western European levels, which is why the labour market has been able to accommodate all graduates, without a surge in graduate unemployment. As a consequence, the labour market return to a higher education degree remains an important factor in the decision to pursue further studies.

\section{Higher education persistence and its influencing factors}

Persistence in higher education, which is identical to endurance, is often considered to be the inverse of attrition. Students' efficiency is not an objectively defined goal of education policy; instead, it is a concept put forward by researchers. Student efficiency includes a successful academic career and constant improvement of students. The successful academic career refers to the scenario when students overcome hurdles in the system easily and do not discontinue their studies. The concept also includes loyalty to the chosen programme and institution. Endurance in the studies is an important component of success, which contains the value of education perceived by the student and the determination to graduate (Pusztai, 2015). Astin (1993) argues that higher education persistence can be measured by the commitment to graduate as well as the by the time and effort invested into education. Persistence is influenced by various factors.

According to Tinto's model of attrition (1975; 1993), the commitment to graduate is affected by social background variables, such as the family background, social relationships, prior studies, student employment, and social integration. Tinto's model focuses on students' institutional embeddedness. Less integrated students are likelier to face attrition than their embedded peers. Tinto suggests that students of unfavourable socio-economic status are at a greater risk of attrition. Various studies (Butlin, 2000; Grayson, 1997; Krahn, 2004; Lehmann, 2007) underline that an unfavourable socio-economic status and the lack of an intellectual background lead to the student entering higher education as an outsider in the cultural sense. In contrast, young adults from the middle and upper classes are able to integrate faster into the academic sphere, which is not far from their primary environment of socialisation (Bourdieu, 1971; Nash, 1990). Lehmann's (2007) research reveals that middle-class students face attrition primarily due to academic difficulties. Conversely, the most frequent reasons for attrition among students of lower status are exclusion and difficulties with integration. Bennett (2003) points out that a favourable financial situation has a positive impact on the commitment towards one's studies. Students whose family pays for the tuition are more motivated, have better results, and are less likely to resort to student employment.

If it is the student who covers tuition and not the state, another challenge arises. For such programmes, the applicant must decide whether to take on the difficulties associated with assuming the financial burden. Potential solutions include part-time studies, student employment, and student loans. Financial difficulties and student employment are likely to result in attrition (Stratton et al., 2005).

The student's gender also influences persistence. According to data from the OECD, the share of females who finish their higher education studies is significantly higher than the male share. However, if members of one gender represent a minority in a given programme, their achievement is usually below the majority average (Hovdhaugen et al., 2015).

As for the field of study, STEM programmes (Science, Technology, Engineering and Mathematics) exhibit higher attrition rates than other fields of higher education, despite the severe lack of STEM graduates in the European labour market. In certain STEM programmes (e.g., computer science), the phenomenon should be characterised as premature discontinuation of studies instead of attrition. This is explained by the fact that such students often get employed before graduation (Lassible-Gómez, 2008). 


\section{Hypotheses}

H1: According to our hypothesis, career-conscious students decide to pursue further studies by taking into account primarily the predictions of human capital theory (well-paying jobs obtainable through a higher education degree, ease of finding employment, and entering a prestigious profession), are more committed to graduate (i.e., are more persistent), and are willing to make considerable effort to this end (Tóth, 2018; CEDEFOP, 2017).

H2: Based on Tóth's (2018) qualitative survey, we hypothesise a higher attrition risk for those who enter higher education due to parental pressure; that is to say, we presume that they are less persistent.

H3: As for traditional gender roles, we hypothesise that males consider financial and career goals more often in their decision about higher education, while females, who identify with the classic "good girl" role, are more persistent (Fényes, 2014; Hovdhaugen et al., 2015).

H4A: We presume that students from a better social background are more persistent (Butlin, 2000; Grayson, 1997; Krahn, 2004; Lehmann, 2007; Bourdieu, 1971; 1977; Nash, 1990; Bennett, 2003) and, in relation to higher education, deem professional career goals more important (Thompson-Subich, 2006).

H4B: According to our alternative hypothesis, based on Ceglédi (2018), we also hypothesise that students from a disadvantaged background who take part in higher education currently are indeed persistent and career-conscious.

H5: As regards differences between countries, we presume that financial considerations in students' decisions to pursue further studies are more important in those examined countries where the economic situation is comparatively worse.

H6: We also presume that self-funded students consider financial factors in relation to higher education to a greater extent than state-funded students. Moreover, those who cover tuition themselves might face financial difficulties and often resort to student employment, which is why they are likelier to drop out and are less persistent (Stratton et al., 2005).

H7A: As for the field of study (Tóth, 2018), students of high-return programmes (e.g., economics or business) deem financial considerations about higher education more important and are more career-conscious and persistent at the same time.

H7B: According to our alternative hypothesis, students of economics, business, and sciences (engineering, computer science, natural science) are not persistent because they are likely to drop out from the programme if they are offered a worthwhile position (Lassible-Gómez, 2008).

\section{Methodological approach}

The database consists of a large-sample student survey ${ }^{2}(\mathrm{~N}=2,199)$, conducted in the academic year 2018/19. The survey was carried out at higher education institutions in Eastern Hungary $^{3}$ and in four other countries ${ }^{4}$ (Slovakia, Romania, Ukraine, Serbia). The sample consists of full-time bachelor's students in their second year and of second-year or third-year students from undivided programmes which offer a master's degree. The Hungarian subsample $(\mathrm{N}=1,034)$ was collected using quota sampling and is representative with respect to faculty,

\footnotetext{
2 Titled: "The Role of Social and Organisational Factors in Student Attrition".

${ }^{3}$ University of Debrecen, University of Nyíregyháza, Debrecen Reformed Theological University, Saint Athanasius Greek Catholic Theological College.

${ }^{4}$ Babeş-Bolyai University (BBTE), Emanuel University of Oradea, Ferenc Rákóczi II Transcarpathian Hungarian College of Higher Education, Constantine the Philosopher University in Nitra, Mukachevo State University, University of Oradea, Partium Christian University (PKE), Sapientia Hungarian University of Transylvania, J. Selye University, University of Novi Sad, Uzhhorod National University.
} 
field of study, and form of funding. At institutions outside Hungary, the aim was probability sampling: groups of students in university/college courses were selected and surveyed exhaustively $(\mathrm{N}=1,165)$.

First, principal component analysis was carried out based on four persistence indicators and 11 variables in relation to motives behind further studies (students marked their agreement or disagreement for each statement on a 1-4 Likert scale; please refer to Table 1 for the statements). Second, the resulting principal components were compared using linear regression with respect to the students' gender, social background, country and field of study, and form of funding, with the gradual inclusion of variables.

We also attempted cluster analysis, using either the original 15 variables or the principal components, which represent attitude types, but the results were difficult to interpret. Nearly all motives and attitudes were important in the first cluster and nearly none in the second, and only the third cluster showed special characteristics. That is why we decided to analyse the effect of background variables on each principal component separately through linear regression and why it was not possible to create a common model with one categorical dependent variable.

The first of our explanatory variables is gender, which has the following distribution in the sample: $30.1 \%$ male and $69.9 \%$ female (1: male, 0 : female). We proxy social background using the father's and mother's years of education (with a mean of 12.7 and a standard deviation of 2.54, and a mean of 12.9 and a standard deviation of 2.6, respectively) and four indicators of financial status. The family's financial situation was measured by the possession of durable consumer goods ${ }^{5}$ (objective financial situation index 0-9, with a mean of 6.9 and a standard deviation of 1.63) and by a relative financial situation indicator, which compares the family's financial situation to the student's peers (on a 1-5 scale where 3 is the average situation, with a mean of 3.3 and a standard deviation of 0.77). To capture the students' individual financial situation objectively, we created a composite index indicating the possession of durable goods ${ }^{6}$ $(0-6$, with a mean of 1.8 and a standard deviation of 1.5$)$ and a subjective indicator of individual financial situation ${ }^{7}$ exploring whether the student can afford a significant purchase or is unable to cover even the basic expenses (1-4, with a mean of 3.2 and a standard deviation of 0.62 ). Finally, the variable for the place of residence at the age of 14 (1: urban, 0: rural) is also included (with $62.2 \%$ of respondents as urban residents). We also investigate the effect exerted by a country variable, which has the following distribution in the sample: $47.5 \%$ Hungary, $32 \%$ Romania, 9.3\% Ukraine, 6.4\% Slovakia, $4.8 \%$ Serbia (we created dummy variables with Serbia as the reference group). Concerning the form of funding, $80.2 \%$ of students were state-funded and $18.9 \%$ were self-funded. We classified the fields of study into five categories: humanities and social sciences $21.5 \%$, economics and business $12.7 \%$, sciences: computer science, engineering, and natural sciences $15.9 \%$, previously unclassified teacher education $25.7 \%$, other $24.2 \%$, and we created four dummy variables, where the reference group was the "other" category ${ }^{8}$.

\footnotetext{
${ }^{5}$ Components of the index: Does the family possess an apartment or house, a five-year-old car or younger, a flat-screen television, a personal computer or laptop with broadband internet access at home, a tablet or e-book reader, mobile internet (on the phone or computer), a dishwasher, an air-conditioner, and a smartphone?

${ }^{6}$ Components of the index: Does the student possess an apartment or house, a car, an above-average smartphone (e.g. iPhone), an above-average computer or laptop, a tablet or e-book reader, and savings for house purchase?

${ }^{7}$ 1: Often I do not have enough money for basic everyday necessities. 2: Sometimes I do not have enough money for everyday expenditures. 3: I have everything I need but cannot afford larger expenditures. 4: I have everything I need and can also afford larger expenditures.

${ }^{8}$ The level of education (i.e., bachelor's programme or undivided programme which offers a master's degree) was not included due to substantial correlation with the field of study.
} 


\section{Results}

Table 1. The results of principal component analysis based on the 4 items of persistence and 11 items of motives behind further studies (factor weights above 0.4 are underlined once; below 0.4 , twice)

\begin{tabular}{lrrrr}
\hline & \multicolumn{4}{c}{ Component } \\
\cline { 2 - 5 } & 1 & 2 & 3 & \multicolumn{1}{c}{4} \\
\hline My studies will be useful in my professional career. & $\underline{0.431}$ & $\underline{-0.426}$ & 0.188 & 0.289 \\
\hline I am very committed to graduate. & $\underline{0.445}$ & $\underline{\underline{-0.59}}$ & 0.183 & 0.176 \\
\hline I aim for the best academic results possible. & $\underline{0.484}$ & $\underline{-0.547}$ & 0.208 & 0.115 \\
\hline I do everything in my power to attend lectures, seminars, and & $\underline{0.444}$ & $\underline{-0.527}$ & 0.243 & 0.102 \\
practice session. & & & & \\
\hline To find a well-paying job. & $\underline{0.492}$ & 0.301 & $\underline{\underline{-0.55}}$ & $\underline{0.408}$ \\
\hline To have a prestigious profession. & $\underline{0.632}$ & 0.127 & $\underline{\underline{-0.502}}$ & 0.25 \\
\hline To advance my knowledge. & $\underline{0.626}$ & -0.215 & -0.119 & $\underline{\underline{-0.408}}$ \\
\hline To find my calling. & $\underline{0.527}$ & -0.179 & -0.149 & $\underline{\underline{-0.559}}$ \\
\hline Because it is easier to find employment with a degree. & $\underline{0.501}$ & 0.273 & -0.266 & -0.01 \\
\hline Because I did not want to start working yet. & 0.224 & $\underline{0.558}$ & 0.374 & 0.084 \\
\hline To establish several relationships. & $\underline{0.49}$ & 0.288 & 0.086 & -0.162 \\
\hline To follow the family tradition. & 0.267 & $\underline{0.444}$ & 0.378 & 0.259 \\
\hline I can afford it financially. & $\underline{0.437}$ & $\underline{0.401}$ & 0.393 & 0.122 \\
\hline I do not have to pay tuition. & 0.321 & 0.36 & 0.364 & -0.244 \\
\hline The hope of social mobility and breaking loose from my & $\underline{0.409}$ & 0.325 & -0.031 & -0.222
\end{tabular}
environment.

The eigenvalue of the four principal components is larger than 1, the total variance explained is $53.54 \%$, and communalities exceed 0.25 .

Source: own data

Based on factor weights, the principal components were named the following:

1. Career-conscious and persistent attitude

2. Family-driven and non-persistent attitude

3. Poorly motivated and not career-oriented attitude

4. Solely financially oriented attitude

The principal component analysis reveals that our first two hypotheses have been supported; in other words, persistence and the consideration of the predictions of human capital theory are common among students simultaneously, while those who are motivated to enter higher education by family tradition are not particularly persistent. However, two other types seem to have emerged, as well: the poorly motivated and not career-oriented attitude and the solely financially oriented attitude. Linear regression was used to examine the relationship between the four attitudes and background variables. 
Table 2. Linear regression results for the career-conscious and persistent attitude as dependent variable, with the gradual inclusion of explanatory variables ${ }^{9}(\mathrm{~N}=2,199)$

\begin{tabular}{|c|c|c|c|c|c|c|}
\hline & Beta & sign. & Beta & sign. & Beta & sign. \\
\hline Gender (1: male) & -0.071 & 0.006 & -0.075 & 0.004 & -0.093 & 0.001 \\
\hline Mother's years of education & 0.02 & 0.512 & 0.018 & 0.564 & 0.011 & 0.735 \\
\hline Father's years of education & 0.06 & 0.051 & 0.06 & 0.052 & 0.055 & 0.078 \\
\hline $\begin{array}{l}\text { The family's objective } \\
\text { financial situation (1-9) }\end{array}$ & 0.063 & 0.03 & 0.072 & 0.016 & 0.065 & 0.029 \\
\hline $\begin{array}{l}\text { The family's relative } \\
\text { financial situation (1-5) }\end{array}$ & 0.051 & 0.082 & 0.045 & 0.125 & 0.052 & 0.083 \\
\hline $\begin{array}{l}\text { Individual objective } \\
\text { financial situation (1-6) }\end{array}$ & 0.053 & 0.066 & 0.051 & 0.08 & 0.055 & 0.062 \\
\hline $\begin{array}{l}\text { Individual subjective } \\
\text { financial situation (1-4) }\end{array}$ & 0.042 & 0.138 & 0.045 & 0.112 & 0.038 & 0.187 \\
\hline $\begin{array}{l}\text { Place of residence at } 14 \text { (1: } \\
\text { urban) }\end{array}$ & -0.057 & 0.03 & -0.058 & 0.03 & -0.062 & 0.022 \\
\hline \multicolumn{7}{|l|}{ Country (ref: Serbia) } \\
\hline Hungary & & & 0.006 & 0.876 & -0.008 & 0.849 \\
\hline Romania & & & 0.03 & 0.442 & 0.031 & 0.447 \\
\hline Ukraine & & & 0.026 & 0.389 & 0.024 & 0.412 \\
\hline Slovakia & & & -0.049 & 0.085 & -0.036 & 0.215 \\
\hline Funding (1: state-funded) & & & & & 0.1 & 0.000 \\
\hline \multicolumn{7}{|l|}{ Field of study (ref: other) } \\
\hline Humanities & & & & & -0.018 & 0.578 \\
\hline Economics or business & & & & & 0.103 & 0.001 \\
\hline Sciences & & & & & -0.041 & 0.174 \\
\hline Teacher education & & & & & -0.088 & 0.015 \\
\hline Adjusted R-squared & 0.033 & & 0.034 & & 0.057 & \\
\hline
\end{tabular}

Source: own data

The career-conscious and persistent attitude is more prevalent among women, people from rural background, and families with objectively more favourable financial situation. It is common among self-funded students and business or economic students, while it is not typical for teacher education students (accounting for different social backgrounds in certain fields of study and form of funding). The parents' level of education, other indicators of financial situation, and the country of study do not influence this attitude.

\footnotetext{
${ }^{9}$ Here and in other linear regression models, explanatory power is relatively low. However, we did not attempt to create comprehensive explanatory models; instead, our intention has been to investigate the direction and significance of effects exerted by certain featured variables.
} 
Table 3. Linear regression results for the family-driven and non-persistent attitude as dependent variable, with the gradual inclusion of explanatory variables $(\mathrm{N}=2,199)$

\begin{tabular}{|c|c|c|c|c|c|c|}
\hline & Beta & sign. & Beta & sign. & Beta & sign. \\
\hline Gender (1: male) & 0.160 & 0.000 & 0.157 & 0.000 & 0.142 & 0.000 \\
\hline Mother's years of education & 0.045 & 0.135 & 0.04 & 0.194 & 0.038 & 0.214 \\
\hline Father's years of education & 0.042 & 0.175 & 0.039 & 0.205 & 0.034 & 0.272 \\
\hline $\begin{array}{l}\text { The family's objective } \\
\text { financial situation (1-9) }\end{array}$ & 0.068 & 0.019 & 0.055 & 0.059 & 0.052 & 0.08 \\
\hline $\begin{array}{l}\text { The family's relative } \\
\text { financial situation (1-5) }\end{array}$ & 0.054 & 0.065 & 0.058 & 0.048 & 0.074 & 0.012 \\
\hline $\begin{array}{l}\text { Individual objective } \\
\text { financial situation (1-6) }\end{array}$ & -0.021 & 0.454 & -0.028 & 0.329 & -0.029 & 0.311 \\
\hline $\begin{array}{l}\text { Individual subjective } \\
\text { financial situation (1-4) }\end{array}$ & -0.048 & 0.09 & -0.037 & 0.194 & -0.033 & 0.235 \\
\hline $\begin{array}{l}\text { Place of residence at } 14 \text { (1: } \\
\text { urban) }\end{array}$ & -0.009 & 0.737 & 0.006 & 0.814 & 0.01 & 0.695 \\
\hline \multicolumn{7}{|l|}{ Country (ref: Serbia) } \\
\hline Hungary & & & 0.085 & 0.034 & 0.038 & 0.386 \\
\hline Romania & & & 0.023 & 0.552 & -0.006 & 0.885 \\
\hline Ukraine & & & 0.12 & 0.000 & 0.109 & 0.000 \\
\hline Slovakia & & & 0.082 & 0.004 & 0.105 & 0.000 \\
\hline Funding (1: state-funded) & & & & & 0.053 & 0.047 \\
\hline \multicolumn{7}{|l|}{ Field of study (ref: other) } \\
\hline Humanities & & & & & 0.05 & 0.11 \\
\hline Economics or business & & & & & 0.097 & 0.001 \\
\hline Sciences & & & & & 0.088 & 0.003 \\
\hline Teacher education & & & & & -0.055 & 0.124 \\
\hline Adjusted R-squared & 0.042 & & 0.056 & & 0.078 & \\
\hline
\end{tabular}

Source: own data

The family-driven and non-persistent attitude is stronger among men and students from families with a relatively favourable financial situation. Furthermore, the attitude is also more frequent in the subsample from Ukraine and Slovakia, for state-funded students, and among students of economics, business, and science (engineering, computer science, natural science) (also accounting for different social backgrounds in certain countries, fields of study, and forms of funding). The attitude is not affected by the parents' level of education, the individual financial situation, and the place of residence. 
Table 4. Linear regression results for the poorly motivated and not career-oriented attitude as dependent variable, with the gradual inclusion of explanatory variables $(\mathrm{N}=2,199)$

\begin{tabular}{|c|c|c|c|c|c|c|}
\hline & Beta & sign. & Beta & sign. & Beta & sign. \\
\hline Gender (1: male) & -0.073 & 0.005 & -0.045 & 0.084 & -0.001 & 0.979 \\
\hline Mother's years of education & 0.036 & 0.234 & 0.059 & 0.054 & 0.058 & 0.056 \\
\hline Father's years of education & 0.063 & 0.041 & 0.063 & 0.039 & 0.069 & 0.026 \\
\hline $\begin{array}{l}\text { The family's objective } \\
\text { financial situation (1-9) }\end{array}$ & -0.142 & 0.000 & -0.124 & 0.000 & -0.118 & 0.000 \\
\hline $\begin{array}{l}\text { The family's relative } \\
\text { financial situation (1-5) }\end{array}$ & 0.134 & 0.000 & 0.124 & 0.000 & 0.143 & 0.000 \\
\hline $\begin{array}{l}\text { Individual objective } \\
\text { financial situation (1-6) }\end{array}$ & -0.002 & 0.935 & -0.008 & 0.774 & -0.013 & 0.645 \\
\hline $\begin{array}{l}\text { Individual subjective } \\
\text { financial situation (1-4) }\end{array}$ & 0.02 & 0.49 & 0.017 & 0.545 & 0.016 & 0.574 \\
\hline $\begin{array}{l}\text { Place of residence at } 14 \text { (1: } \\
\text { urban) }\end{array}$ & 0.036 & 0.165 & 0.062 & 0.02 & 0.069 & 0.009 \\
\hline \multicolumn{7}{|l|}{ Country (ref: Serbia) } \\
\hline Hungary & & & -0.206 & 0.000 & -0.127 & 0.003 \\
\hline Romania & & & -0.086 & 0.026 & -0.012 & 0.758 \\
\hline Ukraine & & & -0.029 & 0.318 & -0.001 & 0.967 \\
\hline Slovakia & & & -0.009 & 0.745 & -0.033 & 0.249 \\
\hline Funding (1: state-funded) & & & & & 0.093 & 0.000 \\
\hline \multicolumn{7}{|l|}{ Field of study (ref: other) } \\
\hline Humanities & & & & & 0.005 & 0.878 \\
\hline Economics or business & & & & & -0.106 & 0.000 \\
\hline Sciences & & & & & -0.078 & 0.009 \\
\hline Teacher education & & & & & 0.102 & 0.004 \\
\hline Adjusted R-squared & 0.033 & & 0.052 & & 0.089 & \\
\hline
\end{tabular}

Source: own data

The poorly motivated and not career-oriented attitude is more common among the children of highly educated fathers, students from families with an objectively underprivileged but relatively favourable financial situation, and urban students. Furthermore, the attitude is more pronounced among state-funded and teacher education students, and less pronounced among Hungarian students and economics, business, and science (engineering, computer science, natural science) students (also accounting for different social backgrounds in certain countries, fields of study, and forms of funding). The attitude is not affected by mother's level of education and the individual financial situation. 
Table 5. Linear regression results for the solely financially oriented attitude as dependent variable, with the gradual inclusion of explanatory variables $(\mathrm{N}=2199)$

\begin{tabular}{|c|c|c|c|c|c|c|}
\hline & Beta & sign. & Beta & sign. & Beta & sign. \\
\hline Gender (1: male) & 0.044 & 0.083 & 0.04 & 0.122 & 0.005 & 0.859 \\
\hline Mother's years of education & -0.006 & 0.852 & -0.009 & 0.761 & -0.015 & 0.625 \\
\hline Father's years of education & 0.076 & 0.014 & 0.074 & 0.016 & 0.075 & 0.015 \\
\hline $\begin{array}{l}\text { The family's objective } \\
\text { financial situation (1-9) }\end{array}$ & 0.004 & 0.89 & 0.011 & 0.702 & 0.028 & 0.348 \\
\hline $\begin{array}{l}\text { The family's relative } \\
\text { financial situation (1-5) }\end{array}$ & 0.111 & 0.000 & 0.104 & 0.000 & 0.082 & 0.005 \\
\hline $\begin{array}{l}\text { Individual objective } \\
\text { financial situation (1-6) }\end{array}$ & 0.081 & 0.005 & 0.072 & 0.012 & 0.054 & 0.061 \\
\hline $\begin{array}{l}\text { Individual subjective } \\
\text { financial situation (1-4) }\end{array}$ & 0.043 & 0.126 & 0.048 & 0.086 & 0.05 & 0.078 \\
\hline $\begin{array}{l}\text { Place of residence at } 14 \text { (1: } \\
\text { urban) }\end{array}$ & -0.015 & 0.56 & -0.011 & 0.674 & -0.01 & 0.704 \\
\hline \multicolumn{7}{|l|}{ Country (ref: Serbia) } \\
\hline Hungary & & & 0.087 & 0.03 & 0.038 & 0.383 \\
\hline Romania & & & 0.105 & 0.006 & 0.067 & 0.096 \\
\hline Ukraine & & & 0.068 & 0.021 & 0.069 & 0.019 \\
\hline Slovakia & & & 0.024 & 0.406 & 0.033 & 0.246 \\
\hline Funding (1: state-funded) & & & & & -0.119 & 0.000 \\
\hline \multicolumn{7}{|l|}{ Field of study (ref: other) } \\
\hline Humanities & & & & & -0.09 & 0.004 \\
\hline Economics or business & & & & & 0.067 & 0.023 \\
\hline Sciences & & & & & 0.022 & 0.466 \\
\hline Teacher education & & & & & -0.072 & 0.044 \\
\hline Adjusted R-squared & 0.045 & & 0.048 & & 0.079 & \\
\hline
\end{tabular}

Source: own data

The solely financially oriented attitude is more frequent among the children of highly educated fathers and students from families with a relatively favourable financial situation. In addition, it is common in the Ukrainian subsample, as well as among self-funded and economics or business students. By contrast, it is less pronounced among students of humanities (including social sciences) or those in teacher education (also accounting for different social backgrounds in certain countries, fields of study, and forms of funding). Gender, the mother's level of education, the family's objective financial situation, the individual subjective financial situation, and the place of residence exert no effect on this attitude.

\section{Conclusions}

Our hypothesis, which states that career-conscious students decide to pursue further studies by taking into account primarily the predictions of human capital theory and that they are more committed to graduate (i.e., are more persistent), has been supported because the first principal component carries both elements of career consciousness. It has also been confirmed 
that those who enter higher education to follow the family's example have a higher chance of attrition, that is, they are less persistent. However, two other attitude types seem to have emerged, namely the poorly motivated and not career-oriented attitude and the solely financially oriented attitude.

As for the relationship with background variables and gender in particular, contrary to our third hypothesis, females are more career-conscious and also more persistent, while males are likelier to exhibit the family-driven and non-persistent attitude. The lack of career consciousness among men might be explained by shifts in gender roles and men's better social status, resulting in the decision to enter higher education based on the family's example and not on career goals.

With respect to social background, students from rural families with objectively favourable financial situation are more career-conscious and persistent, while the family-driven and non-persistent attitude is more common among those from a relatively well-off family. Furthermore, the poorly motivated and not career-oriented attitude are more frequent among highly educated urban fathers' children, who are in an objectively disadvantaged but relatively favourable financial situation, whereas the solely financial attitude is exhibited by the children of well-educated fathers and relatively wealthy families. In summary, there is evidence for both the original and the alternative fourth hypothesis, which implies that the effect of social background on career consciousness and persistence is ambiguous. It is an interesting additional finding that the individual financial situation and the mother's level of education do not affect the listed attitudes.

In accordance with our fifth hypothesis, the solely financially oriented attitude is more prevalent in Ukraine than in the other analysed countries, which might be explained by comparatively unfavourable economic conditions in the country. In addition, the family-driven and non-persistent attitude is also stronger in the Ukrainian subsample.

By investigating the form of funding with the different social backgrounds and fields of study taken into account, we have found that state-funded students exhibit the career-conscious and persistent attitude as well as the family tradition-based and non-persistent attitude. We have also revealed that the poorly motivated and not career-oriented attitude is more common among state-funded students, while the solely financially oriented attitude is more frequent among selffunded students, which is in accordance with our sixth hypothesis.

Finally, our findings about the field of study show that, despite the high return, economics or business students are likely to display the family-driven and non-persistent attitude as well as the career-conscious and persistent attitude or the solely financially oriented attitude, which confirms both H7A and the alternative H7B hypotheses. Furthermore, the family-driven and non-persistent attitude is common even in science fields (engineering, computer science, natural sciences); in other words, such students, if offered a great position, have the risk of dropping out, which is in accordance with the H7B alternative hypothesis. The poorly motivated and not career-oriented attitude is characteristic of teacher education and humanities, where potential earnings are relatively low.

\section{Discussion}

In this study, we conclude that males are not persistent and career-conscious despite their more favourable social background, which should be considered by education policy. We have found ambiguities in relation to the social background, that is to say, it is not just those from a disadvantaged background who are at risk of attrition or are not particularly careerconscious. Among the analysed countries, it is primarily Ukrainian students who are solely financially oriented in relation to further studies, presumably due to economic difficulties in the 
country. As for the form of funding, self-funded students are motivated by financial considerations more, but education policy ought to take into account that some state-funded students are poorly motivated and not career-oriented. Economics, business, and science students face the risk of attrition, which also requires policy intervention, whereas the lack of career consciousness is common in humanities, where it would be necessary to advertise the wage premium of a higher education degree over a secondary one.

Our quantitative analysis is limited in that the explanatory power of the regression models is relatively low. While we did not attempt to create comprehensive explanatory models but to investigate the effects exerted by certain featured variables, it is plausible to include even more independent variables in the future. In addition, we also aim to conduct qualitative research to explore career consciousness and persistence by field of study, for example through focus group interviews.

\section{Acknowledgments}

Project no. 123847 titled "The Role of Social and Organisational Factors in Student Attrition" has been carried out in the framework of the CHERD-Hungary research group, with support from the National Research, Development and Innovation (NFKI) Office, and with funding from the K-17 grant programme.

\section{References}

Arthur, M. B., Khapova, S. N., \& Wilderom, C. P. (2005). Career success in a boundaryless career world. Journal of Organizational Behavior, 26(2), 177-202.

Astin, A. W. (1993). Preventing students from dropping out. San Francisco. Jossey-Bass.

Balica, M., Fartuşnic, C., Horga, I., Jigău, M. \& Voinea, L. (2000). Perspective asupra dimensiunii de gen în educaţie. [Perspectives on the Gender Dimension in Education] Bucureşti: In stitutul de Ştiinţe ale Educaţiei, UNICEF- Ed. Marlink.

Becker, G. (1964). Human Capital. New York: National Bureau of Economic Research. Columbia University Press

Bennett, R. (2003). Determinants of undergraduate student drop out rates in a university business studies department. Journal of Further and Higher Education, 27(2) 123-141.

Bourdieu, P. (1971). Systems of education and systems of thought. In: Young, M. F. D. (eds.): Knowledge and control: New directions for the sociology of education. London: CollierMacmillan. 189-207.

Bourdieu, P. (1977). Cultural reproduction and social reproduction. In: Karabel, J.- Halsey, A. H. (eds.): Power and Ideology in Education. New York: Oxford University Press. 487511.

Butlin, G. (2000). Determinants of university and community college leaving. Education Quarterly Review. 6(4) 8-2.

CEDEFOP. (2017). Guidance: supporting youth to manage their careers. https://bit.ly/2QKCGqp downloaded 04-01-2020.

Ceglédi, T. (2018). Resilience and higher education. Is the potential of resilience fulfilled or are social inequalities reinforced in higher education? Theses of Doctoral (PhD) Dissertation. University of Debrecen DOI:10.13140/RG.2.2.19764.55685

Clark, B. R., \& Trow, M. (1966). The organizational context. In Wilson, T. M. and Wilson, E. K. (Eds.), College peer groups: Problems and prospects for research. Chicago: Aldine, 17-70, 
Connor, H., \& Britain, G. (2004). Why the difference?: A closer look at higher education minorityethnic students and graduates. DfES Publications Nottingham. http://www.bristol.ac.uk/ethnicity/documents/educationreport.pdf downloaded 04-012020

Csillag, M., Scharle, Á., Molnár, T., \& Tóth, E. (2018): Fiatalok a munkaerőpiacon és az iskolában - változások 2002 és 2018 között. [Young people in the labour market and education - Changes between 2002 and 2018.] In: Csillag, M. and Hermann, Z. Scharle, Á. (eds.): Közelkép. Fiatalok az iskolában és a munkaerőpiacon. [Close-up. Young people in education and the labour market], 37-47. https://www.mtakti.hu/wpcontent/uploads/2019/12/mt_2018_hun_33-150.pdf downloaded 11-01-2020

Fényes, H. (2014). Gender Role Attitudes among Higher Education Students in a Borderland Central-Eastern- European Region called 'Partium'. CEPS Journal 4(2), 49-70.

Galasi, P. (2005). Labour Market Success of Higher-education Graduates. In: Fazekas, K. Varga, J. (eds.):The Hungarian labour market: Review and analysis. Budapest: Hungarian Employment Foundation, Institute of Economics HAS, 93-100.

Galasi, P. (2007). Earnings of higher-education graduates. In: Fazekas, K.-Kézdi, G. (eds.): The Hungarian labour market. Review and analysis. Budapest: Hungarian Employment Foundation, Institute of Economics HAS, 104-122.

Grayson, J. P. (1997). Academic achievement of first-generation students in a Canadian university. Research in Higher Education, 38(6), 659-676.

Hall, D. T. (1996). Protean careers of the 21st century. The Academy of Management Executive, 10(4), 8-16.

Houle, C. O. (1961). The inquiring minds. A study of the adult who continues to learn. Madison: University of Wisconsin Press.

Hovdhaugen, E., Kottmann, A., \& Thomas, L. (2015). Dropout and Completion in Higher Education in Europe. Luxembourg: Education and Culture.

Kazi, S. A. \& Akhlaq, A. (2017). Factors Affecting Students' Career Choice. Journal of Research and Reflections in Education. 11(2), 187-196.

Kertesi, G. \& Köllö, J. (2007). Graduate earnings in 1992-2005. In: Fazekas, K.-Kézdi, G. (eds.): The Hungarian labour market. Review and analysis. Budapest: Hungarian Employment Foundation, Institute of Economics HAS, 78-85.

Knutsen, D. W. (2011). Motivation to pursue higher education. http://digitalcommons.olivet.edu/edd_diss/26 downloaded 04-01-2020

Kot= Кот M. I. (2017): Професійна мотивація студентів як спосіб активізації навчання/ [Professional motivation of students as a way to activate learning] M. І. Кот //Збірник наукових праць [Херсонського державного університету]. [Collection of Scientific Articles "Pedagogical Sciences" (of Kherson State University)] Педагогічні науки. Вип. 75(1). - С. 130-132.

Krahn, H. (2004). Choose your parents carefully: Social class, post-second- ary education, and occupational outcomes. In: J. Curtis, E. G.-Guppy, N. (eds.): Social inequality in Canada: Patterns, problems, and policies. Toronto. Pearson Prentice Hall, 187-203.

Lassible, G. \& Gómez, I. N. (2008). Why do higher education students drop out? Evidence from Spain. Education Economics 16(1). 89-105.

Lehmann, W. (2007). "I just didn't feel like I fit in": The role of habitus in university dropout decisions. Canadian Journal of Higher Education. 37(2) 89-110.

Lepper, M. R. (1988). Motivational considerations in the study of instruction. Cognition and Instruction 5(4), 289-309.

Mincer, J. (1958). Investment in human capital and personal income distribution. The Journal of Political Economy, 66(4), 281-302. 
Nash, R. (1990). Bourdieu on education and social and cultural reproduction. British Journal of Sociology of Education, 11(4), 431-447.

Nimra, S., Nawaz, A. \& Samiullah, S. (2019). Factors influencing career choices. IBT Journal of Business Studies, 15(1), 33-46.

Pires, A. L. (2009). Higher education and adult motivation towards lifelong learning. An empirical analysis of university post-graduates perspectives. European Journal of Vocational Training, 46(1), 129-150.

Pusztai, G. (2015). Pathways to success in higher education. rethinking the social capital theory in the light of institutional diversity. Higher Education Research and Policy (HERP), 7. Frankfurt am Main: Peter Lang Edition.

Schultz, T. W. (1971). Investment in Human Capital; The Role of Education and of Research. New York: The Free Press

Stratton, L., O 'Toole, D. M., \& Wetzel, J. N. (2005). A multinomial logit model of college stopout and dropout behaviour, IZA Discussion Papers, №1634. 144.

Sullivan, S., Forret, M., Carraher, S., \& Mainiero, L. A.(2009). Using the kaleidoscope career model to examine generational differences in Work attitudes. Career Development International, 14(3), 284-302.

Teichler, U., \& Kehm, B. M. (1995). Towards a new understanding of the relationships between higher education and employment. European Journal of Education, 30(2) 115-132.

Thompson, M. N., \& Subich, L. M. (2006). The relation of social status to the career decisionmaking process. Journal of Vocational Behaviour 69(2). 289-301.

Tinto, V. (1975). Dropout from higher education: a theoretical synthesis of recent research. Review of Educational Research. 45(1), 89-125.

Tinto, V. (1993). Leaving college: Rethinking the causes and cures of student attrition. Chicago: University of Chicago Press.

Tóth, D. A. (2018). Elbukni a rajt után - Továbbtanulás és lemorzsolódás a Debreceni Egyetemen a képzési területek tükrében. [Failing after the start - Further studies and attrition at the University of Debrecen with respect to fields of study] In: Pusztai, G.Szigeti, F. (eds.): Lemorzsolódás és perzisztencia a felsőoktatásban. [Attrition and persistence in higher education] Debrecen: Debrecen University Press, 225-238.

Tuckman, B. (1974). An age-graded model for career development education. Journal of Vocational Behavior, 4(2), 193-212. 